\title{
Detection of Leishmania tropica Using Nested-PCR and Some of Their Virulence Factors in Thi-Qar Province, Iraq
}

\author{
Mohammed Hassan Flaih ${ }^{1^{*}}$ \\ Fadhil Abbas Al-Abady ${ }^{2}$ \\ Khwam Reissan Hussein ${ }^{1}$
}

\begin{abstract}
${ }^{1}$ Medical Laboratory Department, Al-Nasiriya Technical Institute, Southern Technical University, Thi-Qar, Iraq.
${ }^{2}$ Department of Biology, College of Education for pure Sciences, University of Thi-Qar, Thi-Qar, Iraq.

"Corresponding author: moh.alqurayshi@stu.edu.iq ", fadhil.abbas1.bio@utq.edu.iq, krhussein@ stu.edu.iq

*ORCID ID: https://orcid.org/0000-0001-9824-6778*, https://orcid.org/0000-0001-8735-7771, https://orcid.org/0000$\underline{0003-4178-7922}$
\end{abstract}

Received 8/12/2019, Accepted 24/8/2020, Published 30/3/2021

This work is licensed under a Creative Commons Attribution 4.0 International License.

\begin{abstract}
:
Cutaneous leishmaniasis is one of endemic diseases in Iraq. It is considered as widely health problem and is an uncontrolled disease. The aim of the study is to identify of Leishmania species that cause skin lesions among patients in Thi-Qar Province, South of Iraq, also to detect some virulence factors of $L$. tropica. This study includes three local locations, Al-Hussein Teaching, Suq Al-Shyokh General and AlShatrah General Hospitals in Province for the period from the beginning of December 2018 to the end of September 2019. The samples were collected from 80 patients suffering from cutaneous leishmaniasis, both genders, different ages, various residence places and single and multiple lesions. Nested-PCR technique was used to amplify kinetoplast minicircle fragments DNA $(k D N A)$. Conventional-PCR was performed for determination of some virulence factors (LPG1, GP63, CPA and PPG1 genes). The electrophoresis findings of $k D N A$ gene showed two species of the parasite found in the study area, 65 samples were positive for cutaneous leishmaniasis, L. tropica at $750 \mathrm{bp}$ and L. major at 560bp. Generally, L. tropica $(57.5 \%)$ was the most common specie and L. major (23.75\%) appeared in a low level. There are no significant differences between the infections of males and females, while there are significant differences at the comparison between age groups. All virulence genes ( $L P G 1, G P 63, C P A$ and PPG1) appeared in all L. tropica isolates with high percentage (100\%). L. tropica is the major specie which that caused CL in Thi-Qar province, while $L$. major appeared in low incidence. The virulence genes, which were reviewed, are necessary and important in pathogenesis of $L$. tropica.
\end{abstract}

Keywords: CPA, GP63, KDNA, Leishmania tropica, LPG1, PPG1.

\section{Introduction:}

Cutaneous leishmaniasis (CL) is considered as a global health problem, it is caused by the intracellular protozoa that belongs to the Leishmania genus, that is transmitted by the bite of the sand fly species (1). The most common leishmaniasis form is $\mathrm{CL}$ which infects skin epidermis to form papule usually painless and chronic, often at site of infected sand fly bite (2). Leishmania tropica and L. major cause CL and have same life cycle, but they are spread in different localities and have different intermediate and reservoir hosts (3). The disease transmits into human when human, sand fly and the reservoir share same the environment (4). L. tropica causes anthroponotic cutaneous leishmaniasis (ACL), while L. major causes the zoonotic cutaneous leishmaniasis (ZCL) (5). Leishmania must evade from the innate and adaptive immune responses. It is engulfed by macrophage but resist proteolysis and degradation in the phagolysosome (6). An infection of any type of Leishmania depends on complex, virulence factors and host immunologic response (7). Leishmania produces various virulence factors to facilitate transmission of parasite and infect mammalian host (8). Lipophosphoglycan (LPG) has an important role not only in invertebrate and vertebrate host, but too during early steps for the establishment of the infection (9). However, LPG plays an important role to avoid of the parasite lysis by the host complement system, either by preventing complement molecule attachment or inactivate the assembly of complement complex on the promastigote surface (10). It binds with complement receptor (CR3) and anchored 
molecules on macrophage surface to facilitate parasite engulfment (11). LPG1 is one of the key enzymes in the LPG biosynthesis, that are involved in the synthesis of the LPG glycan core. As well as, Leishmania that lack lpgl gene express incomplete LPG, not contain PG domain (12). GP63 is as known leishmanolysin or is called Major Surface Protease (MSP) or promastigote surface protease (PSP), also it is called a zinc- dependent metalloprotease (13). GP63s vary in their sequence (especially in untranslated regions), array in the Leishmania genome $(14,15)$. GP63 cleaves complement protein $\mathrm{C} 3 \mathrm{~b}$ and converts to $\mathrm{C} 3 \mathrm{bi}$, this leads to silent entry of parasite into macrophage (16). GP63 is responsible for a migration of the parasite through the extracellular matrix, avoid lysis by the complement system, evasion from macrophagic intracellular hydrolysis $(12,17)$. Cysteine proteases (CPs) are degrading enzymes which cleave various proteins, as well play an essential role in many pathogenic protozoa and other microorganisms (18). CPs appear to have an essential role in pathogenicity, modulation or evasion of the host immune response, cell/ tissue degradation and damage, catalyze hydrolysis of various host proteins differentiation of promastigote and autophagy $(19,20)$. There are several types of PPGs, including filamentous proteophosphoglycan and GPI-anchored membranous proteophosphoglycan (21). PPG is proved to bind to macrophage receptors in order to facilitate parasite invasion; this may explain that PPG plays an early role in infection and the prevalence $(22,23)$. The PPG1 gene encodes a membrane-bound PPG (24). Lima et al. (25) confirmed a role of L. infantumderived LPG which it plays in the pro-inflammatory response in Leishmania infection. Mohammad and Hmood (26) recorded gp63 and GIPLs by a ratio of $100 \%$ in all L. major samples in AL-Qadisiyah Province in Iraq.

Despite of the importance of cutaneous leishmaniasis, and to our knowledge, there is limited information about Leishmania species prevalent in the area. This study aims to identify Leishmania species that cause human skin lesions in Thi-Qar Province, south of Iraq by kinetoplast minicircle DNA gene, as well as determine some virulence genes of L. tropica.

\section{Materials and Methods: \\ Study area and sample collection}

The protocol of this study was approved by management of training and human development department/ Thi-Qar Health Office (32877 at 2/12/2018). The study includes three locations to the samples collected: Al-Hussein
Teaching, Suq Al-Shyokh General and Al-Shatrah General Hospitals in Thi-Qar Province, South of Iraq for the period from the beginning of December 2018 to the end of September 2019. The hospitals have received patients suffering from cutaneous diseases. All medical information was taken from the hospital records. Written consent is obtained from all participants by the collector and the participation in the study is voluntary and they were free to withdraw at any time from the study. The samples were collected from lesion fluid of 80 patients with CL, both genders, different ages, various residence places in the province and from single and multiple lesions. Expected skin infection lesions were injected using normal saline $(0.2 \mathrm{ml})$ in lesion edge, then pulled again, after that the fluid was kept in plain tube $(27,28)$.

\section{Genomic DNA extraction}

DNA was extracted from lesion fluid using gSYAN DNA kit extraction kit Geneaid according to protocol of produced company (Geneaid/ Taiwan). DNA concentration was examined using a Nanodrop spectrophotometer and then stored at $20^{\circ} \mathrm{C}$ until used in PCR amplification.

\section{Nested-PCR amplification}

The $k D N A$ was amplified for identification of Leishmania isolates, using Nested-PCR, with some modification of PCR according to (29), which included two steps. Target DNA undergone the first run with external primers: CSB2XF and CSB1XR (Table 1), then the first run product undergone second run with internal specific primers: $13 Z$ and LiR.PCRmaster mix was prepared by (AccuPower ${ }^{\circledR}$ PCR PreMix kit. Bioneer, Korea). Nested PCR primers were provided by Macrogen Company, Korea. Nested PCR master mix prepared $5 \mu \mathrm{L}$ of genomic DNA, 10 pmol of each external primer and $13 \mu \mathrm{L}$ of PCR water and placed in standard PCR tubes. Thermal condition of the PCR reaction included an initial denaturation at $95^{\circ} \mathrm{C}$ for 5 min followed by 30 cycles at $95^{\circ} \mathrm{C}$ for 30 sec., $55^{\circ} \mathrm{C}$ for $30 \mathrm{sec}$. and $72^{\circ} \mathrm{C}$ for $1 \mathrm{~min}$ and finally final extension $72^{\circ} \mathrm{C}$ for $5 \mathrm{~min}$. A nested PCR master mix of second run included $3 \mu \mathrm{L}$ of first run product, 10 pmol of each internal primer and $15 \mu \mathrm{L}$ of PCR water and placed in standard PCR tubes with thermal conditions for the PCR reaction. The PCR products passed electrophoresis in $1 \%$ agarose gel with $3 \mu \mathrm{L}$ of ethidium bromide. PCR product $(10 \mu \mathrm{l})$ was added into each comb well and $5 \mu \mathrm{l}$ of (100bp ladder) in each well. Gel tray was fixed in electrophoresis chamber and filled by $1 \mathrm{X}$ TBE buffer. The electric current was connected at 100 volts and $80 \mathrm{~mA}$ for 1 hr. PCR products were visualized using an ultraviolet transilluminator. 


\section{Conventional-PCR amplification}

The PCR technique was performed for detecting virulence factor genes in L. tropica. This method was carried out according to the method described by Al-Difaie (27). The primers were provided by Macrogen company, Korea. PCR master mix prepared $5 \mu \mathrm{L}$ of genomic DNA, 10 pmol of each R and F primers and $13 \mu \mathrm{L}$ of PCR water and placed in standard PCR tubes. Thermal conditions and agarose electrophoresis are similar to the above.

\section{Statistical Analysis}

In the study, method of Chi-Square $\left(\chi^{2}\right)$ test was used in order to analyze the data using SPSS statistical package software V.17. Significant level was at $\mathrm{P}<0.05$.

Table 1. Oligonucleotide primers used in Nested PCR in the study

\begin{tabular}{|c|c|c|c|}
\hline $\begin{array}{l}\text { Primer } \\
\text { name }\end{array}$ & Sequence5'-3' & $\begin{array}{ll}\text { PCR } & \text { Product } \\
\text { size } & \\
\end{array}$ & Reference \\
\hline CSB2XF & $\begin{array}{l}\text { ATT TTT CGC GAT TTT CGC AGA ACG } \\
\end{array}$ & $750 \mathrm{bp}$ & (29) \\
\hline CSB1XR & CGA GTA GCA GAA ACT CCC GTT CA & & \\
\hline $13 Z \mathrm{~F}$ & ACT GGG GGT TGG TGT AAA ATA G & 750bp & (29) \\
\hline LiR R & TCG CAG AAC GCC CCT & & \\
\hline LPG1 F & ACG CAT ACG GCA TCT TTT TC & $311 \mathrm{bp}$ & (27) \\
\hline LPG1 R & GCG AAA CAG CTC ATT GTT CA & & \\
\hline $\begin{array}{l}\text { GP63 F } \\
\text { GP63 R }\end{array}$ & $\begin{array}{l}\text { AGCAACACCGACTTCGTGAT } \\
\text { TGCACTTCTCGCTGAGGAAG }\end{array}$ & $565 \mathrm{bp}$ & (26) \\
\hline CPA F & TGGGCTTTGAAAAACCACTC & 437bp & (27) \\
\hline CPA R & CACGAGTTCTTCACGATCCA & & \\
\hline PPG1 F & CAT TAT GGG TGG GAA ACC TG & $568 \mathrm{bp}$ & (27) \\
\hline PPG1 R & GAT GGG CAA GTT AGG TGG AA & & \\
\hline
\end{tabular}

\section{Results:}

Agarose gel electrophoresis results for 80 samples of mitochondrial kinetoplast minicircle fragments DNA $(k D N A)$ gene were amplified by Nested PCR, discovered $65(81.25 \%)$ positive for cutaneous leishmaniasis (contain Leishmania parasite) and $15(18.75 \%)$ negative samples, where observed significant difference $(\mathrm{P}>0.05)$ between them (Table 2). Furthermore, the results showed that two species of the parasite which that found in the study area. Statistically, there is a significant difference between $L$. tropica and $L$. major. $L$. tropica recorded the most common species, while $L$. major was a low incidence. $46(57.5 \%)$ positive samples were L. tropica at 750bp and 19 (23.75\%) positive samples were L. major at 560bp (Fig. 1). There are no significant differences between the infection of $24(30 \%)$ males and $22(27.5 \%)$ females. The age groups $\leq 20,21-40$ and $>40$ years old recorded $33(41.25 \%), 10(12.5 \%)$ and $3(6.5 \%)$ respectively, and showed significant differences (Pvalue $=0.000$ ) when the compared with other age groups.

The electrophoresis results of the PCR product of $L P G 1, G P 63, C P A$ and PPG1 genes observed in all of cutaneous Leishmania which were recorded as $L$. tropica isolates in the study (Figs. 2,3,4 and 5) at $311 \mathrm{bp}, 565 \mathrm{bp}, 437 \mathrm{bp}$ and $568 \mathrm{bp}$ PCR product sizes, respectively.
Table 2. Molecular diagnosis of Leishmania species using Nested PCR

\begin{tabular}{ccccc}
\hline $\begin{array}{c}\text { Leishmania } \\
\text { spp. }\end{array}$ & $\begin{array}{c}\text { Infected } \\
\text { Samples } \\
\text { No (\%) }\end{array}$ & $\begin{array}{c}\text { Positive } \\
\text { Samples } \\
\text { No (\%) }\end{array}$ & $\begin{array}{c}\text { Negative } \\
\text { Samples } \\
\text { No (\%) }\end{array}$ & $\begin{array}{c}\text { P- } \\
\text { value }\end{array}$ \\
\hline L. tropica & $46(57.5)$ & & & \\
& 19 & 65 & 15 & 0.00 \\
L. major & $(23.75)$ & $(81.25)$ & $(18.75)$ & \\
P-value & 0.001 & & & \\
\hline
\end{tabular}

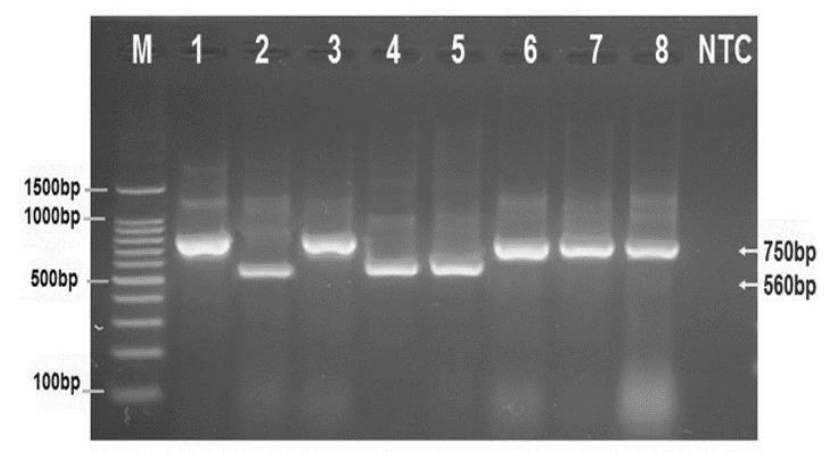

Figure 1. Agarose gel (1\%) electrophoresis that showed Nested PCR product analysis of kDNA in Cutaneous Leishmaniasis positive isolates from human skin lesion. Where M: marker (100$1500 \mathrm{bp}$ ), lanes $1,3,6,7$, and 8 positive of $L$. tropica at 750 bp PCR product size and lanes 2, 4 , and 5 positive of $L$. major at 560 bp PCR product. 


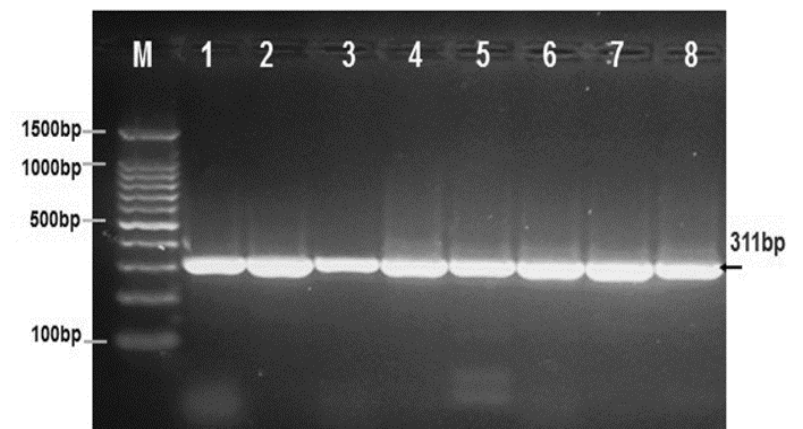

Figure 2. The image of agarose gel (1\%) electrophoresis that showed the PCR product analysis of virulence factor $L P G 1$ gene in $L$. tropica positive samples. Where M: marker (100-1500 bp), lanes 1-8 positive LPG1 at 311 bp PCR product size.

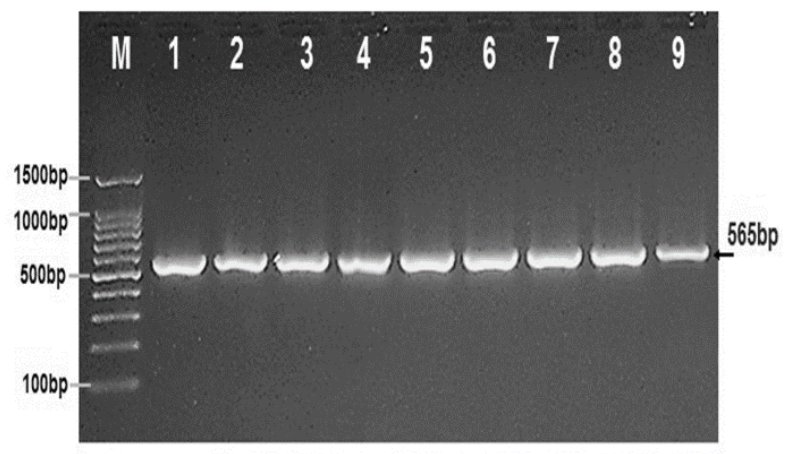

Figure 3. Agarose gel (1\%) electrophoresis that showed the PCR product analysis of virulence GP63 gene in L. tropica positive samples. Where M: marker (100-1500 bp), lanes 1-9 positive GP63 at 565 bp PCR product size.

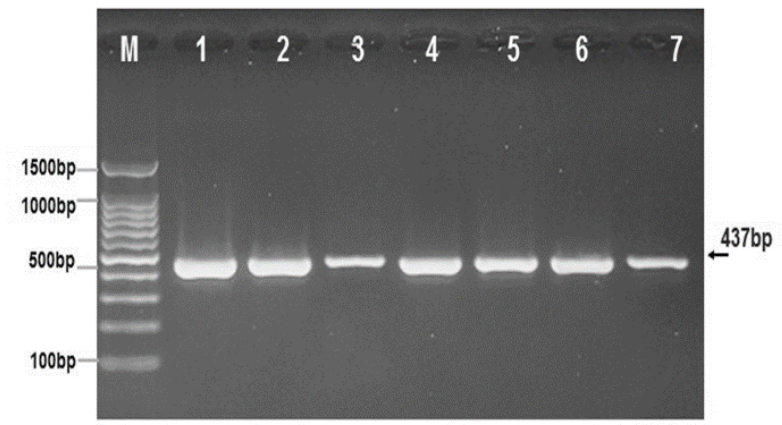

Figure 4. Agarose gel (1\%) electrophoresis image that showed the PCR product analysis of virulence factor $C P A$ gene in $L$. tropica positive samples. Where M: marker (100-1500 bp), lanes 1-7 positive $C P A$ at 437 bp PCR product size.

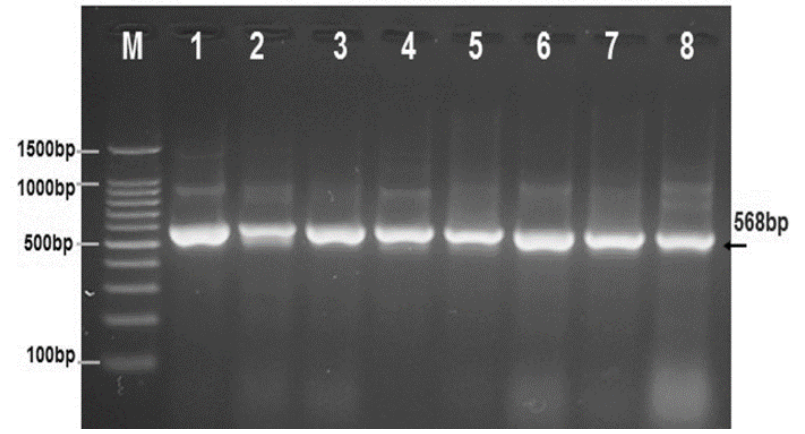

Figure 5. The image of agarose (1\%) gel electrophoresis that showed the PCR product analysis of virulence factor PPG1 gene in $L$. tropica positive samples. Where M: marker (1001500 bp), lanes 1-8 positive PPG1 at 568 bp PCR product size.

\section{Discussion:}

Cutaneous leishmaniasis is an endemic disease in several countries. Foci of $L$. major in Egypt, Jordan, Libya, Sudan and Tunisia, while Afghanistan, Pakistan, Iran, Saudi Arabia, Syria, Iraq, Morocco, and Yemen are endemic for both $L$. tropica and L. major (30). In this study, Leishmania $s p p$. was identified by $k D N A$. Amplification $k D N A$ gene is a suitable coal for differentiating between CL species and numerous diagnostic tests $(31,32)$. $k D N A$ gene is the most sensitive since kinetoplast contains about 10,000 circular and convoluted kDNA minicircles per parasite $(31,33)$.

Lieshmanial DNAs have been recorded in $65(81.25 \%)$ cases and the rest were negative samples. The appearance of negative sample revealed not withdraw the parasite during the collection and may lack DNA in the sample or its crash. In addition, the results have shown that most CL patients in Thi-Qar Province were infected with L. tropica, while $L$. major was in a little number of patients. Geographical expansion and globally increase of leishmaniasis is still associated with vector population expansion (34). Also, increase in migration, rapid urbanization, deforestation and Leishmania adaptation with mammalian hosts and additional vectors (35). CL spread from endemic to non-endemic regions, if both sandfly vectors and reservoir hosts are present (36). The results of current study were no significant differences between infection of the males and the females, this may be due to the fact that Leishmania parasites infect both sexes at the same extent. Furthermore, there is no clear explanation for infection differences according to the gender. It might be individual and behavioral factors that play a role as mentioned in previous studies (37). This result is somewhat close to the results of Al-Difaie (27), AlHassani (28) in Al-Qadisiya Province, Khosravi et 
al. (37), Ghatee et al. (1) in Iran and El Hamouchi et al.(38) in Morocco. This result is inconsistent with Alsamarai and Alobaidi (39) Al-Haweja City and Rahi (40) in Wasit Province.

The study recorded significant differences $(p<0.05)$ between other age groups. The highest rate of infection by L. tropica was among age group of $\leq 20$ years old $(41.25 \%)$, then followed by age group 21-40 years old. This can be explained as a result to previous exposure of the infection which give permanent immune for individuals (39). This is in consistent with the findings of Al-Difaie (27), El Hamouchi et al.(38) and Hassan et al. (41) in Kirkuk City. It is also inconsistent with Rahi (40) in Wasit Province, Khosravi et al. (37) and Ramezany et al.(32) in Iran.

The current study recorded the presence of Lipophosphoglycan (LPG1), leishmanolysin (GP63), Cysteine proteinase A (CPA) and Proteophosphoglycan (PPGl) genes in all of $L$. tropica isolates (100\%). Al-Difaie (27). has found $L P G, P P G$ and $C P$ in all of L. major isolates in AlQadisiya Province. In Brazil, Lázaro-Souza et al. (12) have mentioned a growth of $L$. infantum delayed if deletion of $L P G 1$ gene. L. major mutants which lack $L P G 1$ and $L P G 2$ genes are sensitive to host complement system, this leads to unable survival in both intermediate or definitive host cells (23). GP63 is not only to degradation and damage of transcription factors and various kinases, but also it modulates negative regulatory mechanisms of signaling pathways (15). Cysteine protease inhibition appears as an important strategy for elimination of disease. They are necessary for metabolism, intracellular survival and reproduction of parasite (42). CPA plays an essential key in the interactions of parasite with host cells, but is not important to replication promastigotes (43). Other studies have shown that inhibition of CPA and CPB or deletion their genes not only alters autophagy pathway, but for prevents transformation into amastigotes, thus support the hypothesis of autophagy are required for the differentiation $(44,45)$. Samant et al. (45) have suggested that possibilities of PPG in drug resistance mechanisms and PPG abundance of $L$. donovani is as an evidence for resistant clinical isolates. PPG1 may play a direct important role in host-parasite interactions (46).

\section{Conclusion:}

The importance of Thi-Qar Province comes from frequent infections of CL. As all know, there is a very little data about the identification of Leishmania species responsible of human CL. The findings have showed two species co-existing in the study area that were L. tropica and L. major. The most cases of cutaneous lesions have been infected with L. tropica, that is the prevalent species. Some virulence genes have been investigated which confirmed their necessity and importance in pathogenesis of L. tropica. Therefore, it is essential to conduct more studies on the sandfly vectors and reservoirs of Leishmania species. However, nestedPCR is more suitable for direct diagnosis of Leishmania at species level.

\section{Acknowledgements:}

Out of gratitude, the authors thank the staff of dermatology and laboratory departments in AlHussein Teaching, Suq Al-Shyokh General and AlShatrah General Hospitals for their helping during the sample collection. Also, we would to say thanks for public health department-Thi-Qar health center for their kind assistance. This study did not support financially.

\section{Authors' declaration:}

- Conflicts of Interest: None.

- We hereby confirm that all the Figures and Tables in the manuscript are mine ours. Besides, the Figures and images, which are not mine ours, have been given the permission for republication attached with the manuscript.

- The author has signed an animal welfare statement.

- Ethical Clearance: The project was approved by the local ethical committee in University of Southern Technical.

\section{References:}

1. Ghatee MA, Mirhendi H, Marashifard M, Kanannejad Z, Taylor WR, Sharifi I. Population Structure of Leishmania tropica Causing Anthroponotic Cutaneous Leishmaniasis in Southern Iran by PCR-RFLP of Kinetoplastid DNA. Biomed Res Int [Internet]. 2018;2018:1-11. Available from: https://doi.org/10.1155/2018/6049198

2. Aronson N, Herwaldt BL, Libman M, Pearson R, Lopez-velez R, Weina $\mathrm{P}$, et al. Diagnosis and Treatment of Leishmaniasis: Clinical Practice Guidelines by the Infectious Diseases Society of America ( IDSA ) and the American Society of Tropical Medicine and Hygiene ( ASTMH ). Clin Infect Dis. 2016;63:202-64.

3. Sharma U, Singh S. Immunobiology of Leishmaniasis. Indian J Exp Biol. 2009;47(2009):412-23.

4. Alemayehu B, Alemayehu M. Leishmaniasis: A Review on Parasite, Vector and Reservoir Host. Heal Sci J. 2017;11(4):1-6.

5. Khosravi A, Sharifi I, Fekri A, Kermanizadeh A, Bamorovat M, Mostafavi M, et al. Clinical Features of Anthroponotic Cutaneous Leishmaniasis in a 
Major Focus, Southeastern Iran, 1994-2014. Iran J Parasitol. 2017;12(4):544-53.

6. Martínez-lópez M, Soto M, Iborra S, Sancho D. Leishmania Hijacks Myeloid Cells for Immune Escape. Front Microbiol. 2018;9:1-16.

7. Gupta G, Oghumu S, Satoskar AR. Mechanisms of Immune Evasion in Leishmaniasis Gaurva. Adv. Appl. Microbiol. 2013; 82:155-184. doi: 10.1016/B978-0-12-407679-2.00005-3.

8. Corrales RM, Sereno D, Mathieu-Daudé F. Deciphering the Leishmania exoproteome: What we know and what we can learn. FEMS Immunol Med Microbiol [Internet]. 2010;58(1):27-38. Available from: 10.1111/j.1574-695X.2009.00608.x

9. Atayde VD, Hassani K, Lira S, Borges R, Adhikari A, Martel C, et al. Leishmania Exosomes and other Virulence Factors: Impact on Innate Immune Response and Macrophage Functions. Cell Immunol [Internet]. 2016;1-35. Available from: http://dx.doi.org/10.1016/j.cellimm.2016.07.013

10.Forestier C, Gao Q, Boons G. Leishmania lipophosphoglycan: how to establish structureactivity relationships for this highly complex and multifunctional glycoconjugate? Cellu and Infec Microbiol. 2015;4:1-7.

11.Singh KS. Human Emerging and Re-emerging Infections. 2nd ed. Singapore: Wiley; 2015. 1040 p.

12.Lázaro-Souza M, Matte C, Lima JB, Duque GA, Quintela-Carvalho G, Vivarini ÁC, et al. Leishmania infantum Lipophosphoglycan-Deficient Mutants: A Tool to Study Host Cell-Parasite Interplay. Front Microbiol [Internet]. 2018;9(626):1-10. Available from: doi: 10.3389/fmicb.2018.00626

13.Medina LS, Souza BA, Queiroz A, Guimarães LH, Machado PRL, Carvalho EM, et al. The gp63 Gene Cluster Is Highly Polymorphic in Natural Leishmania ( Viannia ) braziliensis Populations , but Functional Sites Are Conserved. PLoS One. 2016;1-13.

14. Yao C. Major Surface Protease of Trypanosomatids : One Size Fits All ? Infect Immun. 2010;78(1):22-31.

15. Hassani K, Shio MT, Martel C, Faubert D, Olivier M. Absence of Metalloprotease GP63 Alters the Protein Content of Leishmania Exosomes. PLoS One [Internet]. 2014;9(4):1-14. Available from: 10.1371/journal.pone.0095007

16. Oghumu S, Natarajan G, Satoskar AR. Pathogenesis of Leishmaniasis in Humans. Hum Emerg Reemerging Infect. 2015;I:337-48.

17.Contreras I, Gomez M, Nguyen O, Shio M, McMaster R, Olivier M. Leishmania-induced inactivation of the macrophage transcription factor AP-1 is mediated by the parasite metalloprotease GP63. PLoS Pathog. 2010;6(10).

18.Rana S, Mahato JP, Kumar M, Sarsaiya S. Modeling and docking of Cysteine Protease-A (CPA) of Leishmania donovani. J Appl Pharm Sci. 2017;7(9):179-84.

19.Das P, Alam MN, Paik D, Karmakar K, De T, Chakraborti T. Protease Inhibitors in Potential Drug Development for Leishmaniasis. Indian $\mathrm{J}$ Biochem Biophys. 2013;50:363-76.

20.Siqueira-neto JL, Debnath A, Mccall L, Bernatchez
JA, Ndao M, Reed SL, et al. Cysteine proteases in protozoan parasites. NEGLECTROPIC DISE [Internet]. 2018;12(8):1-20. Available from: https://doi.org/ 10.1371/journal.pntd.0006512

21.Mukhopadhyay S, Mandal C. Glycobiology of Leishmania donovani. Indian J Med Res. 2006;123:203-20.

22.Fernandez-prada C, Sharma M, Plourde M, Bresson E, Roy G, Leprohon P, et al. High-throughput CosSeq screen with intracellular Leishmania infantum for the discovery of novel drug-resistance mechanisms Christopher. Drugs Drug Resist [Internet]. 2018;8(2):165-73. Available from: https://doi.org/10.1016/j.ijpddr.2018.03.004

23.Aoki JI, Laranjeira-silva MF, Muxel SM, Floeterwinter LM. ScienceDirect The impact of arginase activity on virulence factors of Leishmania amazonensis. Curr Opin Microbiol [Internet]. 2019;52:110-5. Available from: https://doi.org/10.1016/j.mib.2019.06.003

24.Montgomery J, Curtis J, Handman E. Genetic and structural heterogeneity of proteophosphoglycans in Leishmania. Mol Biochem Parasitol. 2002;121:7585.

25.Lima JB, Araújo-Santos T, Lázaro-Souza M, Carneiro AB, Ibraim IC, Jesus-Santos FH, et al. Leishmania infantum lipophosphoglycan induced- Prostaglandin E2 production in association with PPAR- $\gamma$ expression via activation of Toll like receptors-1 and 2 . Nature. 2017;7:1-11.

26.Mohammad FI, Hmood KA. Detection of Leishmania species by Nested-PCR and virulence factoes GIPLS, GP63 in L. Major by conventional-PCR. Biochem Cell Arch. 2018;18(2):2255-9.

27.Al-Difaie RS. Prevalence of Cutaneous Leishmaniasis in AL-Qadissia province and the evaluation of treatment response by pentostam with RT-PCR. Wasit University /College of Science; 2013.

28.Al-Hassani MKKT. Epidemiological, Molecular and Morphological Identification of cutaneous leishmaniasis and, It's insect vectors in Eastern AlHamzah district,AlQadisiya province. Coll. Educat. AL-Qadisiya Univ.; 2016.

29.Izadi S, Mirhendi H, Jalalizand N, Khodadadi H, Mohebali M, Nekoeian S, et al. Molecular Epidemiological Survey of Cutaneous Leishmaniasis in Two Highly Endemic Metropolises of Iran , Application of FTA Cards for DNA Extraction From Giemsa-Stained Slides. Jundishapur J Microbiol. 2016;9(2):1-7.

30.Postigo JAR. Leishmaniasis in the world health organization eastern mediterranean region. Int $\mathbf{J}$ Antimicrob Agents [Internet]. 2010;36(1):62-5. Available from: doi: 10.1016/j.ijantimicag.2010.06.023

31. Abdolmajid F, Ghodratollah SS, Hushang R, Mojtaba $\mathrm{MB}$, Ali MM, Abdolghayoum M. Identification of Leishmania species by kinetoplast DNA-polymerase chain reaction for the first time in Khaf district, Khorasan-e-Razavi province, Iran. Trop Parasitol. 2015;5(1):50-5.

32.Ramezany M, Sharifi I, Babaei Z, Ghasemi P, Almani 
N, Heshmatkhah A, et al. Geographical distribution and molecular characterization for cutaneous leishmaniasis species by sequencing and phylogenetic analyses of kDNA and ITS1 loci markers in southeastern Iran. Pathog Glob Health [Internet]. 2018;112(3):132-41. Available from: https://doi.org/10.1080/20477724.2018.1447836

33.Azmi K, Nasereddin A, Ereqat S, Schnur L, Schonian G, Abdeen Z. Methods incorporating a polymerase chain reaction and restriction fragment length polymorphism and their use as a ' gold standard' in diagnosing Old World cutaneous leishmaniasis. Diagn Microbiol Infect Dis [Internet]. 2011;71(2):151-5. Available from: http://dx.doi.org/10.1016/j.diagmicrobio.2011.06.004

34.Cunze S, Kochmann J, Koch LK, Hasselmann KJQ, Klimpel S. Leishmaniasis in Eurasia and Africa: geographical distribution of vector species and pathogens. R Soc Open Sci [Internet]. 2019;6:1-12. Available

from: http://dx.doi.org/10.1098/rsos.190334

35.Galgamuwa LS, Dharmaratne SD, Iddawela D. Leishmaniasis in Sri Lanka: spatial distribution and seasonal variations from 2009 to 2016. Parasit Vectors [Internet]. 2018;11(60):1-10. Available from: DOI 10.1186/s13071-018-2647-5

36.Al-bajalan MMM, Al-jaf SMA, Niranji SS, Abdulkareem DR, Al-kayali KK, Kato H. An outbreak of Leishmania major from an endemic to a non-endemic region posed a public health threat in Iraq from 2014-2017: Epidemiological, molecular and phylogenetic studies. PLoS Negl Trop Dis. 2018;12(3):1-11.

37.Khosravi A, Sharifi I, Dortaj E, Afshar AA, Mostafavi M. The Present Status of Cutaneous Leishmaniasis in a Recently Emerged Focus in South-West of Kerman Province , Iran. Iran J Publ Heal. 2013;42(2):182-7.

38.El Hamouchi A, Daoui O, Kbaich MA, Mhaidi I, El Kacem S, Guizani I, et al. Epidemiological features of a recent zoonotic cutaneous leishmaniasis outbreak in Zagora province, southern Morocco. PLoS Negl
Trop Dis. 2019;13(4):1-14.

39.Alsamarai AM, Alobaidi HS. Cutaneous leishmaniasis in Iraq. $\mathrm{J}$ Infect Dev Ctries. 2009;3(2):123-9.

40.Rahi AA. Cutaneous Leishmaniasis in Iraq: A clinicoepidemio-logical descriptive study. Sch J App Med Sci [Internet]. 2013;1(6):1021-5. Available from: http://saspublisher.com/wpcontent/uploads/2013/12/SJAMS161021-1025.pdf

41.Hassan HF, Abbas SK, Shakoor DS. Epidemiological and hematological Investigation of Leishmania major. Kirkuk Unive J Sci. 2017;12(1):457-79.

42.Scala A, Micale N, Piperno A, Rescifina A, Schirmeister T, Kesselringc J, et al. Targeting of the Leishmania mexicana cysteine protease CPB2.8DCTE by decorated fused benzo[b] thiophene scaffol. R Soc Chem. 2016;6:30628-35.

43.Williams RA, Tetley L, Mottram JC, Coombs GH. Cysteine peptidases CPA and CPB are vital for autophagy and differentiation in Leishmania mexicana. Mol Microbiol [Internet]. 2006;61(3):65574. Available from: doi:10.1111/j.13652958.2006.05274.x

44.Denise H, Poot J, Jiménez M, Ambit A, Herrmann DC, Vermeulen AN, et al. Studies on the CPA cysteine peptidase in the Leishmania infantum genome strain JPCM5. BioMed Cent. 2006;13:1-13.

45.Samant M, Sahasrabuddhe AA, Singh N, Gupta SK, Sundar S, Dube A. Proteophosphoglycan is differentially expressed in sodium stibogluconatesensitive and resistant Indian clinical isolates of Leishmania donovani. Parasitol. 2007;134(9):117584.

46.Ilg T, Montgomery J, Stierhof Y, Handman E. Molecular Cloning and Characterization of a Novel Repeat-containing Leishmania major Gene , ppg1 , That Encodes a Membrane-associated Form of Proteophosphoglycan with a Putative Glycosylphosphatidylinositol Anchor. Biol Chem. 1999;274(44):31410-20. 


\section{تحديد طفيلي Leishmania tropica باستخدام تقنية Nested-PCR وبعض عوامل الضراوة في محافظة} ذي قار، العراق

خوام ريسان حسين 1

$$
\text { فاضل عباس العبادي 2 - 20 }
$$

1

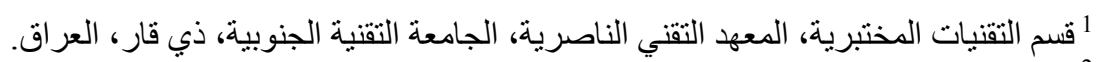

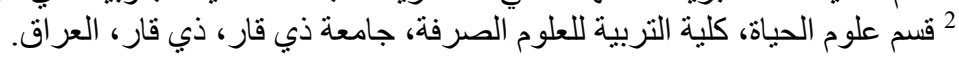

تعد اللثمانيا الجلدية هي واحدة من الامر اض المتوطنة في العراق، وهي تسبب من مشاكل صحية واسعة النطاق فضلا عن كن كونها

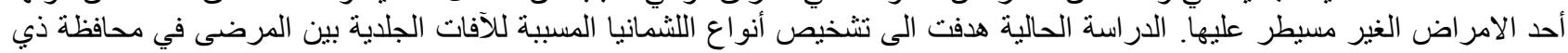

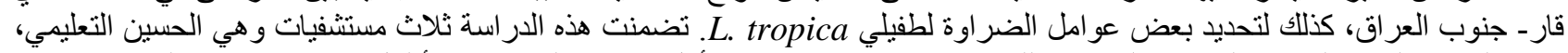
سوق الثيوخ العام و الثطرة العام في المحافظة للفترة من بداية شهر كانون الثاني الأول

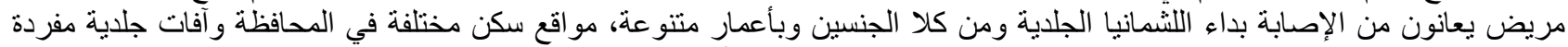

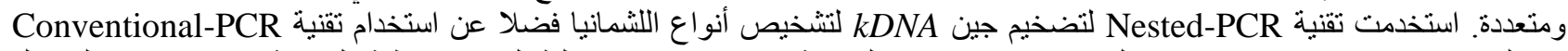

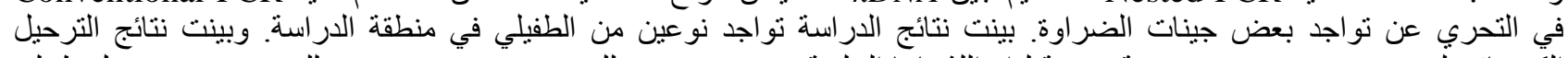
الكهر بائي لجين ب. 2. tropica

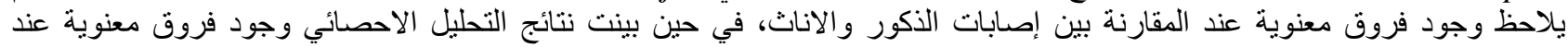

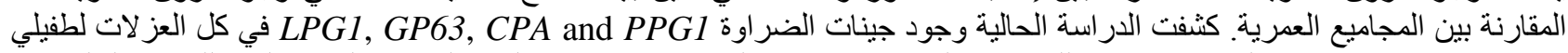
L و L . tropica محافظة ذي قار ، وجينات الضر اوة هي ضرورية ومهمة لإمر اضية الطفيلي. kDNA, PPG1, CPA, GP63, LPG1, Leishmania tropica الكلمات المفتاحية: طفيلي 